\title{
THE AGRICULTURAL INPUT INDUSTRY AND THE COMPETITIVENESS OF SOUTH AFRICAN AGRICUL- TURE
}

J.F. Kirsten ${ }^{1}$

\section{INTRODUCTION}

It is now generally accepted that the future survival and growth of the South African agricultural sector will largely depend on its ability to compete on the world market. Increased agricultural exports, especially of high value agricultural commodities and value-added products, are considered to provide the growth impetus for South African agriculture. This reality and the number of studies being commissioned by government and producer organisations on aspects of the competitiveness of the South African agricultural sector, ensured that the issue of competitiveness has risen to the top of the agenda of the current agricultural debate.

In this paper I address a number of aspects related to the agricultural input industry within the context of the competitiveness of the South African agricultural sector. In view of the dramatic changes in South African agriculture following the process of deregulation (See Kirsten \& Vink, 1999) it is imperative that the agricultural input sector is not analysed in isolation but is discussed as part of the total agribusiness system or agricultural supply chain. Most studies on competitiveness often make the mistake by only considering the output side of the agribusiness system ('from farm to table') and thereby ignoring the possible impact the input sector could have on the competitiveness of the agricultural industry. One objective of my paper is to argue that they should be discussed together since output markets will in the near future to a large degree be influenced by what is happening in the input sector or vice versa. By this I do not suggest that one should debate things such as the price of diesel and other inputs. Instead, there are a large number of fundamental issues, future trends and challenges facing the input industry, which I highlight in Sections 4 and 5. There are however the greater need to be competitive in the world market for agricultural commodities/products as well as the general change in consumers' preferences, which will have a large impact on how the input sector will be structured in the near future. As

1 Department of Agricultural Economics, Extension and Rural Development, University of Pretoria. Deon Scheepers and Marnus Gouse provided valuable research assistance. 
shown below this will also have an impact on how the whole supply chain is structured and managed. Ultimately this will also affect the nature of the relationship between the input sector and the producer. In the end this will influence not only the competitiveness of the agricultural and agribusiness sector but also the ability to satisfy the demands and requirements of the modern consumer of agricultural and food products.

The main part of the paper discuss some global trends in the agricultural input sector which will have a large influence of the nature of the agricultural input sector in South Africa and thus also influencing the nature and competitiveness of South African agriculture per se.

Although the input industry in South Africa does face particular challenges in the context of globalisation and the competitiveness of South African agriculture there is also a range of other aspects related to the smallholder sector which remain particular relevant. This cannot be ignored given the reality of the dualistic nature of South African agriculture. Here the issues relating to input markets are completely different. An analysis and discussion on the agricultural input sector as it relates to the empowerment of black farmers also needs to be done. However given the topic and time allocated to me it will not be possible to address this here. This is perhaps a good topic for separate research in which issues relating to market failures and institutional issues within agricultural input markets can be addressed. Although it is a completely different set of issues it is equally important in terms of the future of South African agriculture in general and the input industry in particular.

\section{A DESCRIPTIVE OVERVIEW OF THE SOUTH AFRICAN AGRICULTURAL INPUT INDUSTRY}

\subsection{Trends in input use and input prices in South African agriculture}

Expenditure by South African farmers on intermediate goods and services during 1998/99 is estimated to be R21 392 million - an increase of $6.8 \%$ on the 1997/98 figure. The individual expenditure on the major intermediate inputs is as follows (National Department of Agriculture, 1999):

Farm feeds

Fertiliser

Maintenance and repairs on machinery and fixed improvements

Packaging material

Dips and sprays

Fuel
R 4896 million

R 2076 million

3774 million

$\mathrm{R} 968$ million

R 2019 million

R 2318 million 
Expenditure on imported intermediate inputs is around R3 000 million or $14 \%$ of total expenditure on intermediate goods and services. The share of total agricultural input expenditure for the major agricultural inputs (using $1997 / 98$ figures) is reflected in Figure 1. Intermediate goods and services those inputs and services consumed in the production process - contributes a total of $51 \%$ of all expenditure while capital expenditure on machinery, implements and fixed improvements is second with a $25 \%$ share.

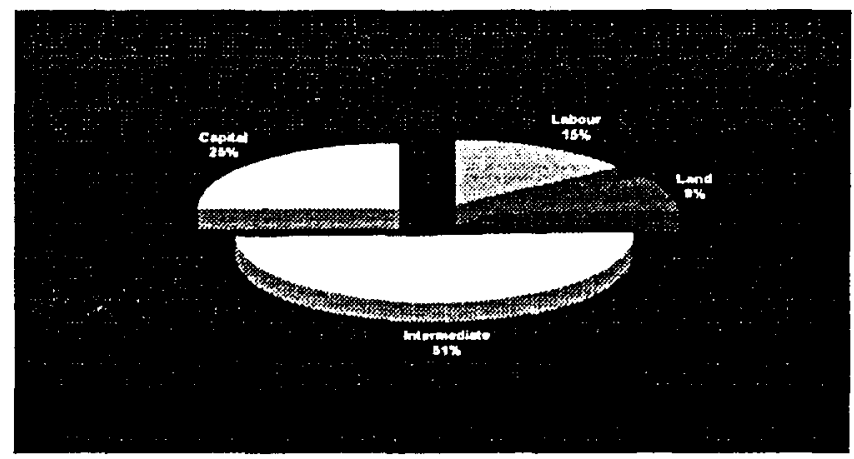

Figure 1: Input expenditure shares: 1997/98

Source: NDA, 1999

Table 1 also reports the average shares in total costs of agricultural inputs, the change in cost shares over the period of 50 years -1947 to 1997 . The change in the shares over time shows that intermediate inputs and capital inputs have been substituted for the primary inputs (land and labour). The cost share of labour dropped from 31 to $15 \%$. Land has stayed more or less constant but increased slightly from 6 to $9 \%$. From Table 1 it seems as if the share of capital expenditure remained constant at around $25 \%$. An analysis of the time series (also Figure 2) however shows that expenditure on capital items (mainly machinery) went as high as $36 \%$ in the mid-sixties as South African farmers invested in tractors. Over the last three years gross capital formation in respect of tractors; machinery and equipment decreased from R2 457 million in 1996 to R1 670 million in 1998. The figures in Table 1 confirmed the trend identified earlier by Thirtle et al, 1993 indicating that all of the input growth is accounted for by the rapid increase in intermediate inputs. This also illustrated by Figure 2.

Increases in the price of farming requisites have always been a major worry to farmers. The sharp increases in these items are illustrated by Figure 3. Table 2 
Table 1: Average share in input costs and annual growth rates, 1947 $1997(\%)$

\begin{tabular}{|c|c|c|c|c|c|}
\hline \multirow{2}{*}{ Item } & \multirow{2}{*}{$\begin{array}{l}\text { Average } \\
\text { share in } \\
\text { input } \\
\text { costs }\end{array}$} & \multirow{2}{*}{$\begin{array}{c}\text { Change } \\
1947 \text { to } \\
1997\end{array}$} & \multicolumn{3}{|c|}{$\begin{array}{l}\text { Annual growth rates for specific } \\
\text { periods }\end{array}$} \\
\hline & & & $1947-97$ & $1987-97$ & $1980-97$ \\
\hline Labour & 18.9 & 31 to 15 & & & \\
\hline Land & 7.8 & 6 to 9 & & & \\
\hline Intermediate: & 44.4 & 38 to 51 & 11.29 & 12.02 & 9.95 \\
\hline Packing & 7.7 & 16 to 7 & 9.82 & 12.12 & 13.81 \\
\hline Fuel & 15.9 & 33 to 18 & 10.20 & 13.43 & 10.68 \\
\hline Fertilizer & 15.9 & 24 to 17 & 10.61 & 9.11 & 8.54 \\
\hline Dips \& sprays & 6.5 & 3 to 13 & 14.76 & 10.92 & 11.65 \\
\hline Animal feeds & 21.4 & 27 to 37 & & & \\
\hline Maint + repairs & 16.9 & 19 to 15 & & & \\
\hline Other & 15.7 & 14 to 17 & & & \\
\hline Capital & 28.8 & 24 to 25 & 0.108529 & 0.118109 & 0.12725 \\
\hline Improvements & 14.3 & 22 to 7 & 0.08391 & 0.081108 & 0.102983 \\
\hline Machinery & 46.8 & 50 to 39 & 0.102916 & 0.09733 & 0.123564 \\
\hline Animals & 40.8 & 28 to 53 & 0.12358 & 0.14456 & 0.134651 \\
\hline
\end{tabular}

Source: Updated and revised from Thirtle ot al., 1993, initially done only until 1991. Note: The totals for intermediate goods provided in the Abstract of Agricultural Statistics were used for the calculations of the shares and are therefore different from Thirtle et al.

provides a summary of the trends illustrated in Figure 3 by calculating the average annual growth rates in the price indices. It is clear that the sharpest increase in requisite prices occurred during the 1980s with prices rising on average at $12,7 \%$ per annum. Annual price increases were substantially lower during the $1990 \mathrm{~s}$ at around $8.7 \%$ on average. This is only an aggregated picture. Recent statistics by the National Department of Agriculture (1999) on the price increase of $11,4 \%$ in the previous year. The price index of machinery and implements increased by $6,3 \%$, requisites for fixed improvements by 7,9 $\%$ and the prices of intermediate goods and services by $2,7 \%$. Prices of trucks and implements showed increases of 5,9 and $7,1 \%$ respectively, while prices of tractors increased by 6,2 . An increase of $11,1 \%$ in the prices of maintenance and sprays made the most significant contribution to the increase in the prices of intermediate goods and services indices for 1998/99 provide some more detail but largely confirm the trend during the 1990s. The all requisites index increased by $3,4 \%$ compared to an. In line with the increase in the prices of farm requisites it is not surprising that the terms of trade in agriculture index 


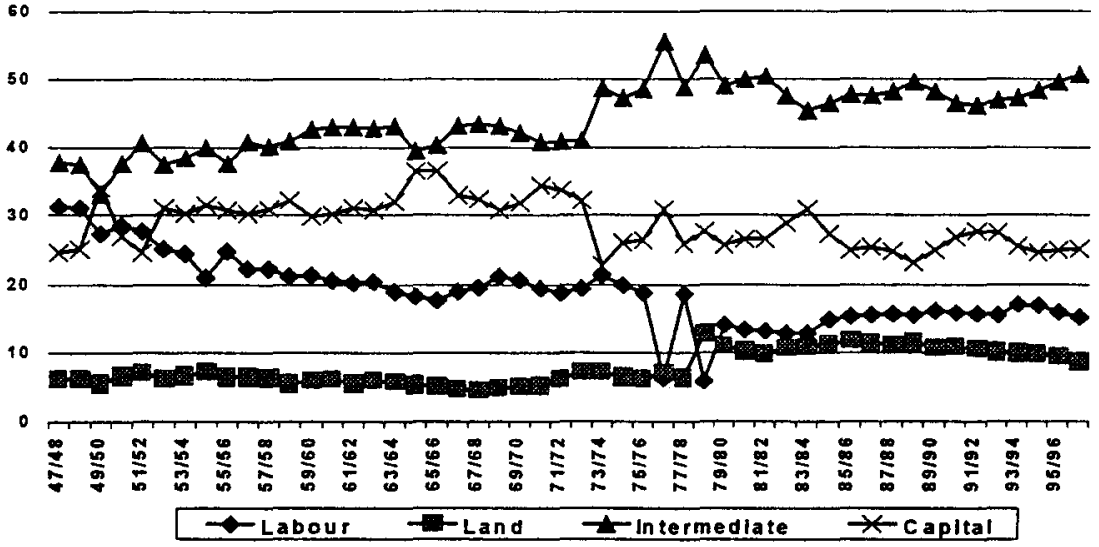

Figure 2: Shares in input costs in South African agriculture: 1947 - 1997

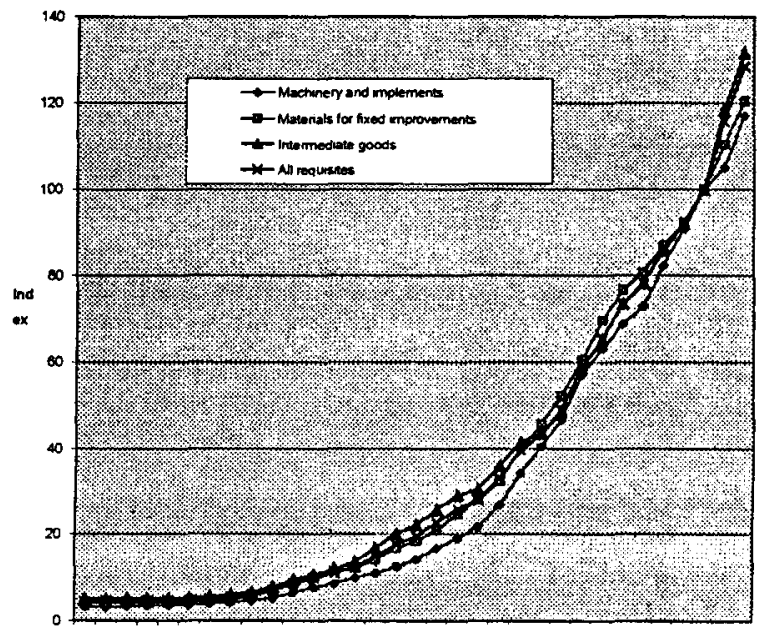

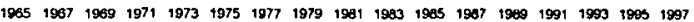

Figure 3: Price indices for farm requisites: 1965 - 1997 
Table 2: Annual growth rates in the price indices for farm requisites for selected periods

\begin{tabular}{|l|c|c|c|c|}
\hline Item & $1965-1997$ & $1965-1980$ & $1980-1990$ & $1990-1997$ \\
\hline Machinery and implements & $11.5 \%$ & $8.9 \%$ & $15.9 \%$ & $8.0 \%$ \\
\hline $\begin{array}{l}\text { Materials for fixed } \\
\text { improvements }\end{array}$ & $10.8 \%$ & $9.2 \%$ & $13.9 \%$ & $7.1 \%$ \\
\hline Intermediate goods & $10.5 \%$ & $9.2 \%$ & $11.3 \%$ & $9.1 \%$ \\
\hline All farm requisites & $10.9 \%$ & $9.3 \%$ & $12.7 \%$ & $8.7 \%$ \\
\hline
\end{tabular}

(indicating the extent to which producer prices in agriculture keep pace with the prices of farming requisites) weakened from a 1 in 1995 to 0,837 at the end of 1998. During 1998. The terms of trade for field crops and horticultural production strengthened from 0,793 to 0,803 and 0,879 to 0,916 respectively. However, in the case of animal production, the terms of trade weakened from 0,864 to 0,816 (NDA, 1999).

\subsubsection{An overview of selected agricultural input industries}

Information on the agricultural input industry is rather sketchy due to the confidentiality of the information. It is therefore not possible to provide a comprehensive picture of market structure and market share in each of the main industries. As a result I only provide a brief overview of the most important industries in terms of market structure, and sales trends as well as tariff protection and imports. The overview will be useful when in section 3 the major trends in the world and South African input industry is discussed. In talking about the future of South African agriculture Section 3 is perhaps more relevant.

\subsubsection{Equipment industry}

Al the leading agricultural machinery and implement manufacturers are represented in South Africa. South Africa has only a small agricultural machinery and implement manufacturing industry with the majority of equipment and machines being imported. Figure 4 below provides the annual tractor sales in South Africa. This is also a true reflection of actual tractor imports because before 1980 no tractors were manufactured and assembled in South Africa (SAAMA, 1999). The tractors manufactured in South Africa annually since then represents only about $5 \%$ of the totals reflected in Figure 4. All imported tractors are subject to a $24 \%$ import tariff, trailers $18 \%$ and stationary engines $15 \%$. All other machines and equipment are imported free of any import tariff. 


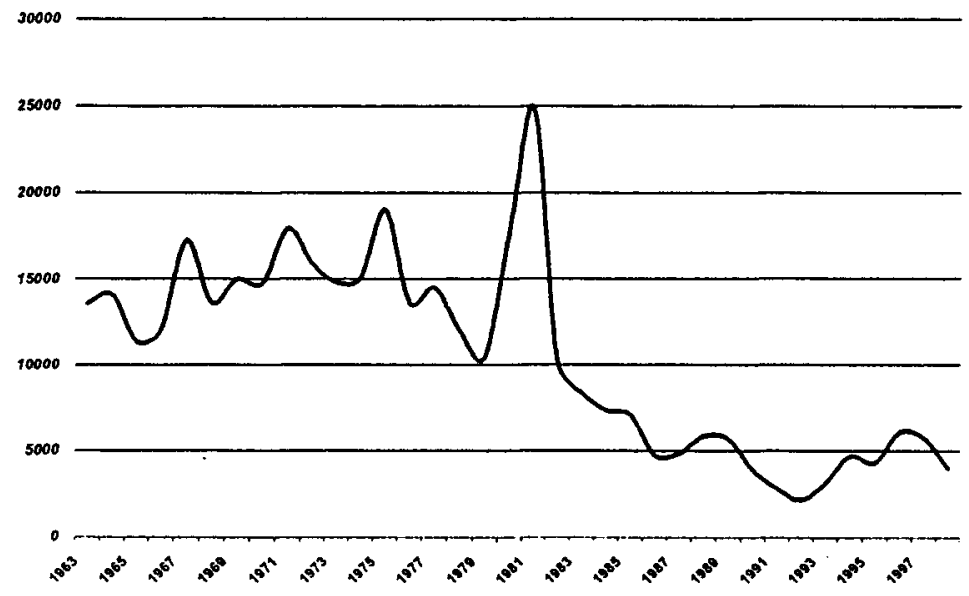

Figure 4: Annual tractor sales by SAAMA members: 1963-1998. (Equal to number imported)

\subsubsection{Seed industry}

The South African seed market has an annual turnover of almost R1 000 million (SANSOR, 1998). Seed for maize and wheat production accounting for $66 \%$ of the seed market, dominates the market. Vegetable seed is second with $18 \%$, followed by pasture/forage with $13 \%$ and flowers with $3 \%$. In total the South African farmer has access to almost 2000 varieties. Most of South Africa's seed requirements is produced locally under contract with farmers and extensive use is made of irrigation to ensure good seed quality.

The agronomic seed market is dominated by hybrid maize with some 230 hybrids available. More than 800 vegetable varieties are on the official lists, half of which are F1 hybrids (Van der Walt, 1997). On July 1, 1989 the South African National Seed Organisation (SANSOR) was officially designated by government as the authority to manage the Seed Certification Scheme. The organisation has 90 members including co-operatives and many of the leading international and local seed companies such as Pioneer Hi-bred and Hygrotech. The organisation has active campaigns to remove levies paid on seed. It was also responsible to negotiate a zero tariff for all imported seed. 


\subsubsection{Fertiliser industry}

The South African fertiliser is largely dominated by 3 primary manufacturers of fertilisers namely Kynoch (a subsidiary of AECI), Sasol and Omnia. There is however one additional manufacturer namely Indian Ocean Fertilisers located at Richards Bay manufacturing mainly for the export market. The nitrogenous components required for fertiliser production are derived from ammonia, which is produced by Sasol and AECI. Phosphate rock is locally mined and used in the manufacture of phosphates by Foskor. Products sold by the fertiliser manufacturers in South Africa include materials prepared from local phosphates, imported components and locally compounded materials. Kynoch, Omnia and Sasol also sell raw materials to a relative large number of secondary manufacturers of specific fertiliser combinations or products whom often also serve a specific geographical region. Some fertiliser manufacturers import most of their raw materials (Venter, 1999).

The annual consumption of fertiliser is estimated at 2083000 tonnes (Venter, 1999). Of this total around 442258 tons (Customs and Excise, 1999) are imported - mainly potash. Fertiliser imports are free and thus local manufacturers are not protected from foreign competition. Despite the fact that fertiliser can be imported free of duty we have not witnessed a large increase in fertiliser imports as shown in Figure 5. Current statistics show that only $20 \%$ of total fertiliser sales are imported.

\subsubsection{Agricultural chemical industry}

Agricultural chemicals include crop protection chemicals and animal health products. There is an active market for agricultural and crop protection chemicals including herbicides, insecticides, fungicides and various other, associated products in South Africa. A large number of international companies, including Bayer, Novartis, Dow Agro Sciences (who recently acquired Sanachem) Zeneca, Rôhne-Poulenc manufacture and distribute agricultural chemicals in South Africa. Companies active in the animal health sector are ICI, Bayer, Pfizer and Hoechst. Raw materials are largely imported from these companies and manufactured and formulated under license here in South Africa. Some companies have their own manufacturing, formulation and/or packaging plant in South Africa. These products are distributed by large distribution networks and local agents.

The total retail sales in the crop protection during 1997 were R1300 million while farmers also spend around R650 million on veterinary medicine. In total the agricultural chemical industry in South Africa is worth around R2 billion. 


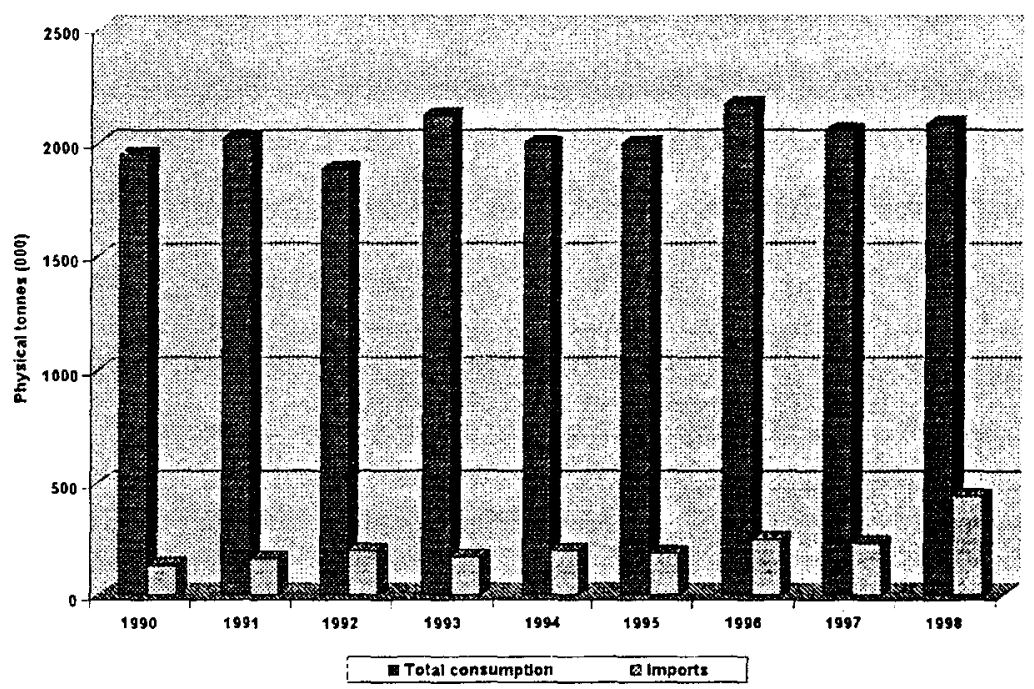

Figure 5: Total fertiliser consumption and imports in South Africa (1990 - 1998)

All agricultural chemicals are imported free of duty into South Africa. According to Customs and Excise statistics (1999) South Africa imported R215 million worth of insecticides fungicides (raw materials as well as already packed) as well as fungicides to the value of R116 million during 1998.

\section{THE HISTORY OF THE AGRICULTURAL INPUT INDUSTRY}

The date when the first family prepared land, planted and harvested a crop cannot be determined, but it is known from archaeological records that, in terms of the history of mankind, agriculture is a recent invention. The development of agriculture and food production since that time can only be described as phenomenal (Johnson, 1997). The continued existence of mankind was secured through the enormous number of problems being solved, difficulties confronted and overcome by farm people across the world assisted by others who created knowledge and organised the production of labour-saving and output enhancing inputs. The application of scientific knowledge according to Johnson (1997) is a recent event, dating only from the middle of the $19^{\text {th }}$ century. Before that invention in improved technology in agriculture was largely the result of the activities of individuals who had little formal research training. 


\subsection{Pre-industrial agriculture}

The events leading to improved technology in agriculture is also well articulated and documented by Terreblanche (1998) in his analysis of economic thought in the pre-industrial phase and during the period of production transformation (1770 - 1870). During this period man finally succeeded to increase production at a rate not known to mankind before. This transformation of production was largely influenced by the works of the economists Francois Quesnay, Adam Smith, Thomas Malthus and David Ricardo - published before or during this period. Between 1200 and 1800 Europe was constantly involved in a battle against continuous poverty (See also Johnson, 1997). In the traditional societies of Europe at that time the majority of the population was not able to satisfy their basic needs of food, clothing, shelter and firewood. Of this food was surely the most important. With 70 to $90 \%$ of the labour force involved in agriculture producing food for home consumption virtually no food or agricultural products were sold on the markets. The only way that these communities could escape poverty was to increase labour productivity in agriculture. This proved to be extremely difficult as a result of a large number of constraints. Some improved grain varieties or animal breeds were developed through individual efforts of the so-called "gentlemen farmers" like Townsend and Young about 50 years before the industrial revolution. These improvements were never dramatic and also not sustainable and also not nearly enough to improve living conditions. Adam Smith and David Ricardo and eventually also Malthus were very pessimistic about the potential of the agricultural sector to improve productivity. The agricultural communities were always the most conservative of society and there was an inherent resistance against change and technological improvement. Before the transformation of production could take place it was necessary to brake this resistance against change. Terreblanche (1998) argues that a number of events during the $18^{\text {th }}$ century prepared the traditional societies of Europe for change and the great transformation. Amongst these were Adam Smith's "Wealth of Nations" and the steam engine of James Watt. Quesnay and the physiocrats pleaded for modernisation in the agricultural sector as a way to escape poverty. After the industrial revolution and the period of the great transformation during the $19^{\text {th }}$ century agricultural changed dramatically. The industrial sector later produced the inputs, which saw a rapid rise in productivity and the eventual modernisation of the agricultural sector. This was an important step in the establishment of the modern industrialised economies of the world.

The period of the transformation of production and more specifically the industrial revolution introduced the agricultural input industry to : world 
agriculture. The institutionalisation of agricultural research across the world continuously provided new innovations (inputs, cultivars, breeds, and machinery) which advanced the agricultural sector even further. As Johnson (1997) mentioned - the growth and development in agricultural and food production was phenomenal.

Since then the nature of agricultural sector changed considerably. The change is however also very dynamic and there still are a number of new global trends, which will change the way we knew agriculture. This will also have an impact on the agricultural input industry. However, as the discussion below highlights, there are many developments in the agricultural input industry that will also change the nature of agriculture. The discussion in this section is largely using the framework of Boellje of al (1995) to illustrate these developments globally. This framework is useful to provide an overview of the forces, which could influence the nature of input markets in the near future but also the nature of farming as we used to know it. In the discussion I also relate these developments and trends to the South African agricultural input industry as far as possible.

\subsection{Post-industrial agriculture}

The greal production transformation of 1770 to 1870 initiated a continuous process of change and modernisation in agriculture in most of the developed nations of the world. During the last three decades (more or less 100 years after the production transformation) dramatic changes have occurred in the agricultural sector. These changes include changes in technology, in the economic climate, in institutional structure and ways of doing business. Agriculture is generally perceived to be in a period of major change and transition. Some authors (Urban, 1991; Drabenstott, 1994; Barry, 1995 and Boehlje, 1996) refer to this transition as the industrialisation of agriculture. By this they mean the application of modern industrial manufacturing, production, procurement, distribution, and co-ordination concepts to the food and industrial product chain (Boehlje, 1996). In an earlier article Boehlje (1995) also talks of the "new" agriculture which requires a totally new approach to management and policy in agriculture. In contrast to the old agricultural system (which was in any case already more modern and industrialised than agriculture in the early $19^{\text {th }}$ century), the new industrialised agriculture moves more toward:

- manufacturing processes (Boehlje (1999) also refers to 'biological manufacturing');

- a systems approach to production and distribution; 
- separation and realignment of the stages in the food chain;

- negotiated coordination among these stages;

- new kinds of risk;

- concerns about system power and control; and

- a more important role for information (Boehlje, 1996: 30)

Boehlje provides a further illustration of this change by comparing old concepts with new concepts of management and strategic thinking of farms and agribusiness. In Table 3 below I list only those concepts which are of particular relevance to the agricultural input industry.

Table 3: Old and new concepts of agriculture

\begin{tabular}{|c|c|}
\hline Old Concept & New Concept \\
\hline Commodities & $\begin{array}{l}\text { Specific attribute/differentiated raw } \\
\text { materials }\end{array}$ \\
\hline Assets drive the business & Customer drives the business \\
\hline $\begin{array}{l}\text { Hard assets (land, machinery } \\
\text { buildings) are the prime source of } \\
\text { strategic competitive advantage }\end{array}$ & $\begin{array}{l}\text { Soft assets (people, organisation, plans) } \\
\text { are the prime source of strategic } \\
\text { competitive advantage }\end{array}$ \\
\hline $\begin{array}{l}\text { Blending of commodity product from } \\
\text { multiple sources }\end{array}$ & $\begin{array}{l}\text { Separation of identity preserved raw } \\
\text { materials }\end{array}$ \\
\hline $\begin{array}{l}\text { Money/finance/assets are the prime } \\
\text { source of power and control }\end{array}$ & $\begin{array}{l}\text { Information is the prime source of } \\
\text { power and control }\end{array}$ \\
\hline $\begin{array}{l}\text { Labour is a cost and equipment an } \\
\text { investment }\end{array}$ & $\begin{array}{l}\text { Labour is an investment and } \\
\text { equipment a cost }\end{array}$ \\
\hline $\begin{array}{l}\text { Adversarial relationship with suppliers } \\
\text { and purchasers }\end{array}$ & Partners with suppliers and purchasers \\
\hline Impersonal sourcing and selling & Relationship sourcing and selling \\
\hline Insourcing (produce your own) inputs & $\begin{array}{l}\text { Outsourcing (buy from someone else) } \\
\text { inputs }\end{array}$ \\
\hline $\begin{array}{l}\text { Outsourcing (buying) from multiple } \\
\text { sources }\end{array}$ & Qualified firm sourcing/sole suppliers \\
\hline $\begin{array}{l}\text { Public/open information and research } \\
\text { and development }\end{array}$ & $\begin{array}{l}\text { Private/proprietary/closed } \\
\text { information and research development }\end{array}$ \\
\hline Consumers believe their food is safe & $\begin{array}{l}\text { Consumers question the safety of their } \\
\text { food }\end{array}$ \\
\hline
\end{tabular}

Source: Boehlje, 1995 
Tweeten \& Zulauf (1998) are however of the opinion that the current changes result mainly from post-industrial factors rather than from industrialisation. Knowledge is the essence of the post-industrial society and "scientific knowledge" the basis for innovation and therefore becomes the ultimate strategic resource. In a post-industrial economy services are critical and dominant. One would for instance see that farmers will spend much less time in the field and more time in service activities such as information gathering, management, marketing, finance and asset acquisition.

Tweeten and Zulauf base their argument for a post-industrial view of agriculture on the works of T.W. Schultz who recognised the role of nonconventional or knowledge inputs of education, research and extension in the massive productivity gains since the 1930s. The characteristics of the postindustrial agriculture are summarised by Tweeten and Zulauf as follows:

- Knowledge-based

- Focus on service activities (marketing, management, finance, etc.)

- Importance of information systems

- Specialisation by services

- Importance of niche markets

- Institutional interactions

Many of the changes and characteristics have been recognised by Boehlje and the other authors on industrialisation. They probably witnessed the same trends but termed it differently. Given the importance of information and knowledge as key inputs in agriculture nowadays I would confer with Tweeten and Zulauf that the concept of "post-industrial agriculture" is perhaps more appropriate. But nevertheless it is clear that agriculture worldwide is experiencing tremendous changes.

\section{CHANGES IN THE AGRICULTURAL INPUT INDUSTRY}

The changing nature of agriculture and agricultural technology changes do have certain implications for the agricultural input industry and brought about a number of changes in the industry - some of which was already mentioned above. This section summarises and takes stock of the major changes.

\subsection{Bundling of inputs}

Producers will increasingly use inputs that match chemical and biological attributes to obtain the optimum quality and characteristics of output. In some 
cases the producer will purchase input packages for combined biological and chemical effectiveness. This provided a new trend of selling and distributing appropriately matched packages of inputs rather than individual inputs such as fertiliser, seed and chemicals (Boehlje, ct al, 1995). Biotechnology (discussed in more detail in Section 5.2.1) provides the potential to match genetic plant material and chemicals to make some varieties more responsive to certain chemicals. With this potential to make inputs more responsive if they are used in the proper combinations, the incentive exists to sell input bundles. As this trend took place agribusiness firms have already or will need to adopt new production as well as marketing and distribution strategies.

The concept of matched inputs can also apply to inputs such as finance and information. Input suppliers have for many y'ears provided convenience credits to buyers of their products (Boehlje et al, 1995). This was mainly to enhance sales and has been payable in 30 to 90 days. The financing strategy of agricultural input firms has changed to provide full season financing at competitive interest rates and some are even pursuing a broader strategy of servicing full financial and credit needs of producers they supply. In this sense we thus saw a development whereby inputs and finance are bundled.

Input suppliers will supply some farm information needs for no or nominal charges as an enticement to use their products. The bundling of information services and physical products will grow in importance and thus presents an alternative to extension agents as a source of advice.

The changes in agriculture will also separate ownership and operation and location of various production activities. In the process new alliances will emerge. Producers increasingly partner with other resource suppliers in various ways to expand volume with limited capital outlays. This phenomenon often occurs through contracting arrangements. The increase specificity in raw material requirements such as protein content of wheat, oil content of soybeans made by food manufacturers will place certain demands on the input and research industry to provide cultivars with these specifics.

\subsection{Knowledge, information and private $R \& D$}

Knowledge and information have become increasingly important resources. Producers must be able to sort through huge amounts of new chemical, biological and other information and put it to practical use. Historically both public (extension services, universities, government) and private sources (input manufacturers, packers and processors) provided information to producers. In contrast many of the new integrated firms or alliances of firms 
have internal research and development staff to enhance their knowledge and information base and is obviously not shared outside the firm or alliance. The pivotal role of knowledge and science will increase the private economic value of knowledge creation and dissemination. As a result intellectual property rights in the agricultural input industry: will become increasingly important as input manufacturers try to capture rents from innovation. As a result we already saw private investments in agricultural and food research and development increasing rapidly in the US and Europe. Private sector investments in agricultural research have been far more that public sector agricultural research spending in many countries since the early 1980s. Most of these private sector expenditures have been for biological and chemical inputs with substantially less spend on research in agricultural machinery and processing.

\subsection{Size and scope of agricultural input firms}

The agricultural input firms have experienced fundamental restructuring over the last 2 decades. This was mainly characterised by the increased concentration in agribusiness firms in the agricultural input industry. The large number of mergers and acquisitions as well as strategic alliances in the input industry over the last couple of years are evidence of this trend, which is likely to continue in the near future (Boehlje et al., 1995). In the US we saw recent merger and acquisition activities by Monsanto acquiring a number of seed companies. This seems to be part of the group's transformation from a plastics and petrochemical company to one of the leading life sciences companies such as Bayer. In Europe the most important developments were:

- the formation of Novartis through the merger between the Swiss pharmaceutical and agrochemical companies Ciba and Sandoz.

- AstraZeneca recently formed from a merger of Swedish pharmaceutical company Astra and the British bioscience company, Zeneca.

Monsanto now does business in 130 countries where they develop, produce and market agricultural technology. Novartis specialises in crop protection and has interests in 60 countries across the world with 6 in Africa. Another example of the size of these so-called "life-science" companies is the large German firm, Bayer, which has an annual turnover of DM54, 9 billion (11\% of 1998 sales in agriculture) employing 120400 people. 
Much of the consolidation is an attempt to use fixed resources more efficiently. Consolidation of input manufacturing and distribution systems is likely to continue for the following reasons (Boehlje, et al., 1995):

- High cost of research and development

- Economies of size in manufacturing and distribution processes

- Obtaining market presence in larger international markets.

In this process of consolidation and as a result of the changing needs of farmers/producers there is also a tendency amongst these large firms to have fewer distribution firms and steps in the distribution channel. Some firms already base their distribution system on the principle of exclusivity. Accordingly, the product range is divided into product categories with different levels of exclusivity. The term "product" which is regularly referred to, is defined as specific trademarks and not active ingredients, with the exception of cases where trading in active ingredients occur.

Most of these changes have taken place in Europe and the US but South African agriculture is not far behind. We will however see a dramatic change in commercial agriculture in South Africa over the next decade. Some of these changes have already taken place but we could see more changes, which will include both technological and institutional innovations.

There are however, a number of factors, which will drive the changes in the agricultural input industry in the near future. Most of these relate to future developments in agricultural research and the process of globalisation.

\section{FACTORS INFLUENCING FUTURE CHANGES IN THE AGRICUL- TURAL INPUT INDUSTRY}

\subsection{Globalisation}

One aspect of the globalisation of agriculture relates to international commodity markets and the impact of various trade negotiations and trade deals on the competitiveness of South African agriculture. I return to the aspect of competitiveness later in more detail in Section 6. This section however, focuses only on a few dimensions of the globalisation process concerning the input markets in particular.

The increased demand globally for agricultural products and the elimination of trade barriers have provided opportunities for agricultural input firms to expand sales and research efforts to other countries. On the one hand we see 
increased exports of agricultural inputs from countries such as the US to other parts of the world but Boehlje, ct al. (1995) also note a trend of substantial offshore "sourcing" of agricultural inputs in the US. Fertiliser material and chemicals are imported into the US from all parts of the world while machinery is manufactured and assembled outside US. In South Africa substantial imports of agricultural inputs and machinery and implements was always a characteristic of the input industry as reflected in Figure 6. Virtually all tractors (except about $5 \%$ ) sold in South Africa are imported. The same applies to combine harvesters and some implements.

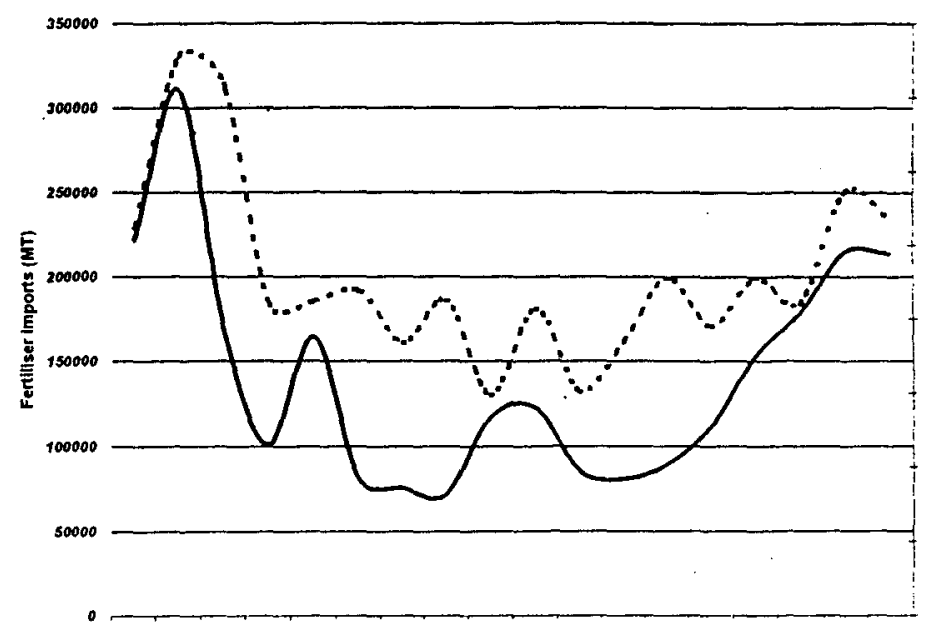

$\begin{array}{llllllllllllllllll}1980 & 1981 & 1982 & 1983 & 1984 & 1985 & 1986 & 1987 & 1988 & 1989 & 1990 & 1991 & 1992 & 1993 & 1994 & 1995 & 155 & 1997\end{array}$

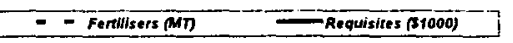

Figure 6: South African fertiliser imports (MT) and the value of imported farm requisites: 1980-1997

Many of the US and European based agricultural input manufacturers have turned their attention to international markets. Since the democratic reforms in South Africa there was a considerable number of large multinational input manufacturers investing in South Africa to expand sales and increase research efforts here. These firms include names such as Monsanto, Novartis, Bayer, Pioneer Hi-bred, Zeneca, etc. Many of the products of these companies have been known to South African farmers but now these multinationals have either merged with local distributors/manufacturers or has acquired a stake (often a controlling share) in local agricultural input firms. In the fertiliser industry for example Norsk Hydro one of the world's largest fertiliser 
companies has acquired a $50 \%$ stake in Kynoch fertiliser while Interore acquired a $50 \%$ share of Senwes' new established fertiliser subsidiary, Porfert both of these developments taking place during 1999. The same trend happened in the chemical and seed industry with investments by Novartis, Monsanto, Dow-Agro Sciences and Pioneer Hi-bred.

In South Africa the number of foreign owned patents for agricultural technologies and research investments by multinational firms expanded - the same trend that happened in many other countries. Agricultural research has also turned global as a result of private firms as well as public research centres doing agricultural research across the world.

\subsection{Advances in agricultural sciences}

Following from the discussion in Section 3 it is true that agriculture has been subject to several waves of innovation over the last 150 years. Earlier mechanical, chemical and biological innovations have reduced labour requirements, increased yields and reduced the impact of pests. Recent innovations in computer and remote sensing technology have improved input precision and agricultural biotechnology will reshape agriculture as profoundly as the first wave of innovations (Zilberman, et al, 1997).

Most of the innovations in agricultural technology come in the wake of increased private sector investment in agricultural research (Frisvold et al, 1998) which is again largely attributable to the expansion of intellectual property rights (IPRs) for biological inventions (Fuglie et al, 1996). Until recently biological inventions were considered products of nature and not afforded legal protection under patent laws.

In this section I discuss the two major new developments in agricultural technology namely agricultural biotechnology (which is largely the result of the developments described above) and precision farming. Both developments will have particular impacts on the way the input industry and agriculture will be structured in the years to come.

\subsubsection{Agricultural biotechnology}

Biotechnology holds great promise in bringing further gains in productivity. Until the 1980s scientists used the genetic potential that already existed in crops and animals by careful crossbreeding. The next step is genetic engineering and cell culture, which has already taken the agricultural and consumer world by storm. These modern plant biotechnology methods have 
led to the development of novel plant varieties that would not have been possible using traditional breeding methods. Genetic engineering simplifies the identification of the genes responsible for desirable traits and allows scientists to precisely transfer single traits between species. Thus, seed developers can decrease the number of unintended characteristics that may occur with traditional breeding methods and speed up the development of new strains.

Genetic engineering of plants became technically feasible in the 1970s, but it was not until the 1990 s that commercial agricultural products became available. Yet by the end of this decade, the majority of oil crops grown in the U.S. and Canada will be genetically engineered, along with significant portions of maize, cotton and potatoes. This represents a possibly historically high adoption rate for a new agricultural technology, yet the sequence and effects remained largely undocumented. At the same time, other profound effects are taking place, including the shift of agricultural research funding from the public to the private sector, the privatisation of agricultural innovations through the use of intellectual property rights (IPR) like patents (as discussed earlier), and a broad-based concern about the safety of genetically engineered foods, particularly in Europe.

Most of the genetically modified crops that are commercially available have been developed to carry herbicide tolerant or insect resistant genes. Crops carrying herbicide-tolerant genes were developed to certain herbicides that previously would have destroyed the crop along with the targeted weeds. This now makes it possible for farmers to use a broader variety of herbicides to control weeds. The most common herbicide-tolerant crops are RoundupReady crops that are resistant to glyphosate and has been incorporated into cotton, maize, soybeans and canola.

Two other examples of genetically engineered inputs and plants are:

- Monsanto's Bollgard Cotton which delivers season-long in-plant control that reduces, or in most cases eliminates, the need to spray for worms. By. managing cotton's worst pests - tobacco budworms, cotton bollworms and pink bollworms - growers can take advantage of the potential for higher crop profitability. Reducing or eliminating the need to spray for worms helps save on equipment, fuel and labor costs that multiply and can eat growers' profits. In-plant protection also provides cotton worm control without worry about breakdown by sunlight and rain, common with traditional insecticide treatments. The environment will also benefit by decreasing insecticide treatments. 
- Monsanto has also developed YieldGard insect-protected maize (marketed locally by Pioneer hi-bred), which is genetically modified for protection against the European corn borer and related insect pests. The protection is provided through a gene derived from a naturally occurring microorganism, Bacillus tiuringiensis ("Bt"). The gene enables maize to produce a protective protein that is highly specific to target pests but harmless to other living things, including mammals and beneficial insects. Corn borers weaken maize plants by feeding on them, causing large losses for farmers. The average yield loss, according to Monsanto is 6 percent but losses can reach 30 percent with heavy infestations. YieldGard allows farmers to control the target pests without chemical insecticides or other resource inputs. Because farmers need only to plant YieldGard corn seed to benefit from the protection, large and small growers can readily use the product alike. No additional machinery, labour or other resources are needed.

These products are all examples of first generation biotechnology products that enhance the production practices of farmers and saving production costs. Over the long run a second generation of biotechnology products could bring even greater benefits to the producer through various quality enhancements such as maize or soybeans with higher protein or oil content, modifications that facilitate processing, or crops designed to produce high value pharmaceuticals or industrial chemicals (Zilberman et al., 1999). This development is in a way a first indication of how the input industry is responding to the requirements of the consumer as part of the new supply chain philosophy I discuss later. Biotechnology will permit development of value-added products that will allow substitution of agricultural for industrial processes in the manufacture of pharmaceuticals and fine chemicals. The adoption of biotechnology is one of the components that form part of the process of transforming agriculture from an industry producing and processing commodities to that manufactures specific attribute raw materials. Biotechnology enables farmers and processors to manipulate the attribute development and deterioration process in plant and animal production.

This technology brings about a number of issues, which require further investigation and research. Here are considerable opportunities for agricultural economists to do research work with their scientific colleagues. These issues are the following:

Farm-Level Effects of Agricultural biotechnology: Adoption levels of biotechnology products, which determine the quantities of products on the markets, are central to the development of this technology. Research in the USA has now made it possible to measure the costs and profits of a number of 
key commodities, including soybeans, corn, cotton, and canola. The research results presented at a recent conference (NE-165 Regional Research Project, 1999) in the US established general agreement that producers on average benefited financially, and that there were environmental benefits in the forms of reduced chemical use and less erosion when herbicide tolerant crops made no-till cultivation more feasible. Unlike most recent technological innovations, the available agricultural biotechnologies tend to reduce rather than increase management requirements.

Private Sector Strategies and Public Acceptnnce: The ultimate effects of agricultural biotechnology will lie in the intersection of public acceptance, corporate strategy, and private use incentives. Public acceptance seems to be moving in the direction of labelling - voluntary or mandatory - but little is presently known. of the acceptable forms of labels, or the decision-making entity for an orderly system. There are early signs that the input industry in the US and Europe is now consolidating, in part to avoid pricing strategies between agricultural biotechnology and traditional input supplier firms. The new consumer demands in the form of traceability could provide some hindrances in the way of full public acceptance of this technology. If consumers are demanding that their food products should have a "nonFrankenstein" origin then it might create problems for this potential beneficial and advantageous technology.

Supply Channels and Regulation: It is important to also explore some of the ramifications of different regulatory rules. applied to agricultural biotechnology products. Clearly, the costs of segregating products in the marketplace (identity-maintained products) will be substantial, at least until the volume increases and the system adjusts from its present commodity focus. But potentially more, significant threats are posed to the world grain and oil products trading system, whether they come from expansive biosafety regulations, as was proposed under the Biodiversity Convention, or through refusals of Europeans to consume genetically modified foods. The latter raises troubling issues of scientific proof of health effects under WTO rules, which appear not to be suited to such strongly felt views.

Institutional Analysis and IPR: Intellectual property rights (IPR), and patents in particular, is a driving force in the evolution of agricultural biotechnology. In future we need to consider mechanisms for mitigating opportunistic use of patent-conferred monopoly rights. Options include compulsory licensing and commercialisation permission for component materials accessed from the private sector. Clearly defined IPRs is critical for the future success and expansion of this technologr: 
Impact on the organisation of sed/pesticide industry: Different industrial structures usually evolve when dramatic technological changes occur. The biotechnology revolution will require that a closer co-ordination between germplasm and pesticide supply with transgenic crops take place than with conventional pesticides and crop varieties. As a result biotech firms will take organisational and marketing steps to improve scale economies, expand sales of the new technologies and increase profits. Carlson et al (1997) discuss some examples of these changes which include:

\section{Organisational changes:}

- Acquisitions

- Mergers

- Purchase genetic resources

\section{Marketing}

- Exclusive sales agreements

- Non-exclusive licences

- Distributing seeds at low cost

- Separate technology fee

- Combined seed and technology pricing

- Tie-in sales

- Regional price discrimination

The trend of mergers and acquisitions was discussed earlier in Section 4.3. The purchase of genetic resources may involve purchase of patents, research expertise, or access to gene libraries. Exclusive agreements restrict the spread of genetic resources more than non-exclusive licences or agreements. The "low-cost seeds" strategy is novel for agriculture, but more or less the same as the strategy of software companies giving away products to developers so that a product can become widely used and seen as an industry standard (Carlson et al., 1997).

The actions listed above will convert separate seed and pesticide industries into a combined industry. Not all of the agreements and relationships are friendly and many conflicts arise as private firms attempt to rapidly enter these markets and keep others out. Currently there are eight major lawsuits involving use of $B t$. 


\subsubsection{Precision agriculture}

Another development in agricultural technology, which could change the nature of the input industry and agriculture, is the introduction of precision farming. Interest in prescription farming has grown as the technology necessary for its implementation has become available. The central concept of prescription farming is that materials (chemicals, fertilisers, and seeds) are optimally applied as a function of position within the field. Therefore, profits are maximised and potential adverse environmental effects are minimised. The technology makes use of digital geographically referenced data obtained from satellite and other sources in farming operations and is the leading example of a cluster of emerging information technologies in agriculture.

Literature addressing precision farming has shown the field and farm-level economic and environmental benefits of site-specific allocation of crop inputs (fertiliser, pesticides, and seeds) ( $c$. Daberkow, 1997). Through promotion of a public commitment and a technical mechanism to mitigate farm chemical pollution, precision farming legitimates chemically based agriculture in an era of rising environmentalism. Further, precision farming is based on, and will advance, the commodification of agricultural information-appropriation of field and farm-level decision processes through substitution of capital for local knowledge. By automating farm-level data collection and information management and by reducing agriculturists' reliance on public sector agricultural research and extension, precision farming supports further integration of on-farm activity into a co-ordinated system of industrial manufacture (Wolf and Wood, 1997).

The technology has a tremendous potential in terms of savings in input costs by assisting farmers in making input application rate decision. The greatest gains from adoption of this technology will likely flow from those inputs used on large numbers of hectares. Nitrogen, phosphates and herbicides are used on over $80 \%$ of the planted acreage of most crops. As a result it could have large environmental benefits. The technology brings to agriculture a new range of inputs mainly from the computer, communications and high tech sector.

\subsection{Integration, co-ordination and partners}

Consumers are more demanding and expect quality control and products with specific characteristics. With the advent of the biotechnology inventions and the larger number of food scares in Europe, consumers will increasingly demand safe food. As a result "traceability" became an important issue for 
consumers and they now demand to know the origin of the product as well as the production process used. The demand for certain characteristics as well as the food safety issue bring about a need for higher degree of interdependence between the different levels of the food system (Boehlje et al., 1995).

There is thus a need for closer co-ordination with many products such as chicken, fruit, speciality soybeans, etc all being produced under contract of varying specificity. The ability to fulfil consumer demands and thus be able to produce to specification will increase and the ability to measure product characteristics will increasingly be important.

Consumer behaviour will just like technology become one of the important driving forces in the agricultural and agribusiness industry in the near future (See also Zuurbier, 1999). The rapid transmission of consumer demands through the supply chain to primary producers and input suppliers will be of great importance if agricultural industries and producers want to compete effectively. The need to comply with consumer demands will force the producers to put certain demands to input suppliers in terms of research and development and new innovations. A supply chain perspective on the food and agricultural industry requires thus that the input industry should be seen as a central part of the chain.

Boehlje et al. (1995) predicted this trend when they argued that the fundamental issue of control in the food system would result in significant new linkages between agribusiness firms, producers and input suppliers with the full range of acquisitions, joint ventures, and-contractual and partnering arrangements being used. The primary motivation for these more integrated systems is to provide more accurate signals to producers and input suppliers as to what the ultimate end user, the consumer wants in his food products. The spot markets are not providing the information effectively and we will therefore see the disappearance of spot markets and the emergence of production contracts to ensure that the product comply with the requirements of the consumer. Most contracts are designed to deal with moral hazard and/or adverse selection problems related to the consumer and quality demands discussed earlier.

Some production contracts could in future also involve provisions on input control (Goodhue, 1999). Input control refers to one a contractual specification on non-labour inputs used in the production process. Motivations for input control in production contracts include the following (Goodhue, 1999). 
- Scheduling of planting time and selection of crop varieties to aid planning for processors.

- Preserving control over intellectual property and the returns. Seed and plant material is not sold to producer - contractors maintain title to seed or propogation material.

- Quality related reasons. Contractors may wish to control inputs that affect quality in order to ensure greater consistency in the final product.

In this process we would therefore see integration (or partnership) of input suppliers, producers and processors to ensure that the "supply chain" comply with the requirements of the consumer and thus be competitive. This issue of competitiveness is discussed next in more detail.

\section{THE INPUT INDUSTRY AND COMPETITIVENESS}

With the agricultural sector in South Africa now largely deregulated, farmers and agribusiness have to position themselves to be competitive in the world market within a less controlled and so-called free market global trading environment. This has now been proved to be critical for the long-term survival of the agricultural industry. It is therefore no wonder that many questions are being asked about the competitiveness of the South African agricultural and agro-food industry. A paper by Van Rooyen et al. (1999) presented at this conference provides a first attempt to answer this question. The purpose of this section is first to highlight the possible influence of the input industry on the competitiveness position of South African agriculture and second to indicate how the issue of competitiveness (and also consumer demands) will create certain demands and pressure on the input sector.

At the 1994 IAAE conference in Harare the central theme was agricultural competitiveness and it is only after about 5 years that this issue has now entered the debate in South Africa. At this conference many papers addressed the topic and tried to define the concept. Petit and Gnaegy (1995) provided the most workable definition of competitiveness; 'Competitiveness is the ability to produce and provide products and services for international markets while ensuring rising levels of real income, at least some portion of which is used to further the development of the economy.' One important factor influencing competitiveness according to Ul Haque (1991) is:

"the ability to absorb, use and develop technology to reduce production costs, to improve product quality and innovate new 
products". This implies an important role for the input industry and specifically the research and development component of the industry. In other words technology is an important factor in enhancing competitiveness

However since these positions on competitiveness have been aired many things have changed and the issue of competitiveness is now approached differently. Based on the work of the agribusiness experts in Europe and the USA it is now been argued that a supply chain focus on competitiveness is necessary (cf. Zuurbier, 1999 and Soler \& Tangury, 1998). This approach emphasises the integrated nature of the supply chain in which all transactions should serve the final consumer (Van Rooyen, et al., 1999) as discussed in section 5.3. As such this approach considers the input supply companies, financiers, co-operatives, processors and the farmer all as part of the food supply chain. Viewed in this context it is obvious why the actions of the input suppliers can influence the ability of the farmer or processors to deliver the product the consumer is demanding. This aspect also follows from the discussion in section 3.5 .

Porter (1990) proposes another framework in which the issue of competitiveness or competitive advantage can be analysed. According to Porter there are 6 attributes that shape the environment in which local firms compete and which promote the creation of competitive advantage. These are:

- Factor conditions

- Demand conditions

- Related and supporting industries

- Firm strategy, structure, and rivalry

- Government attitude and policy

- The role of chance.

In the context of this paper it is in particular his points on factor conditions and related and supporting industries which can be used to argue why the input industry can have an influence on the competitive position of an industry. It is the nation's position with regard to factors of production, natural resources, level of production costs and infrastructure, which can have an impact on the competitiveness of the industry. In addition the presence or absence of supplier industries and related industries such as an efficient agricultural research system will also be an important factor. From a recent study (ISMEA, 1999) of the European Food Industries it was found that the production costs of the major intermediate inputs and labour seems to be the major factors influencing the competitiveness position of the different food 
industries. This suggests that it requires all the elements of the agro-food chain to be integrated to serve the needs of the end-consumer to be able to compete in domestic as well as international markets.

\section{CONCLUSION}

This paper discussed the agricultural input industry against the background of major changes in the agricultural sector across the world. A number of forces shaping the agricultural sector and specific the agricultural input sector in the future have been identified. Specific attention was given to the advances in sciences (especially biotechnology) and the continuous integration of the supply chain to serve consumer needs. In the context of the increasing importance of competitiveness in world agricultural markets it is critical that the agricultural input industry is well integrated and well-aligned with the agricultural value chain to ensure the survival of the agricultural industry. The days of conflict and rivaly between farmers/processors and the input industry are numbered and a successful agricultural industry can only be built on trust and good relations with suppliers and customers.

\section{BIBLIOGRAPHY}

BOEHLJE, M. (1995). The "new" agriculture. Choices. Fourth Quarter: 34-35.

BOEHLJE, M. (1996) Industrialisation of agriculture: What are the implications. Choices. First Quarter: 30-33.

BOEHLJE, M. (1999). Structural changes in the agricultural industries: How do we measuie, analyse and understand them? American journal of Agricultural Economics, 81(5):1028-1041.

BOEHLJE, M.; AKRIDGE, J. \& DOWNEY, D. (1995). Restructuring Agribusiness for the $21^{\text {st }}$ century. Agribusiness, Vol. 11 no. 6: 493-500.

CARLSON, G. MARA, M. \& HUBBEL, B. (1997). The new super seeds: Transgenic Technology for Crop Protection. Choices. Third Quarter: 31-36.

DABERKOW, S. (1997). Adoption rates for selected crop management practices: Implications for precision farming. Choices. Third Quarter: 26-30.

FRISVOLD, G.; FUGLIE, K. \& KLOTZ-INGRAM, K. (1998). Growth of private agricultural research. Choices, Second Quarter. 
FUGLIE, K.; KLOTZ, C. \& GILL, M. (1996). Intellectual property rights encourage private investment in plant breeding. Choices. First Quarter,

GOODHUE, R.E. (1999). Input control in agricultural production contracts. American Journal of Agriculturnl Economics. 81 (3):616-620.

GOPINATH, M. ROE, T.R. \& SHANE, M.D. (1996). Competitiveness of U.S. food processing: Benefits from primary agriculture. Americnn Journal of Agricultural Economics, 78(4):1044-1055.

ISMEA. (1999). The European agro-food system and the challenge of global competition. Rome.

JOHNSON, D.G. (1997). Agriculture and the wealth of nations. (Richard T. Ely Lecture). American Economic Review, 87(2):1-12.

KIRSTEN, J.F. \& VINK, N. (1999). Agricultural policy in South Africa in the 1990s. Unpublished research report. Department of Agricultural Economics, Extension and Rural Development, University of Pretoria. May 1999.

NATIONAL DEPARTMENT OF AGRICULTURE. (1999). Economic review of the South African agriculture: 1998/99. Pretoria, August 1999.

PETIT, M. \& S. GNAEGY. (1995). Agricultural competitiveness and global trade: looking at the future of agriculture through a crystal ball. In: Peters, G.H. and D.D. Hedley (eds.) Agricultural competitiveness: market forces and policy choice. Proceedings of the 22nd International Conference of Agricultural Economists. Dartmouth.

PORTER, M.E. (1990). The competitive advantage of nations. London, Macmillan.

SANSOR. (1998). The South African seed industry: gateway to Africa. Promotion leaflet. SANSOR, Pretoria.

SOLER, L.G. \& TANGUY, H. (1998). Co-ordination between production and commercial planning: organisational issues. Int. Trans. Opl Res. 5(3):171-188.

TERREBLANCHE, S.J. (1998). Die ekonomiese probleem en ekonomiese denke in die voor-industriële fase en tydens die groot transformasie van produksie. Unpublished mimeo. Department of Economics, University of Stellenbosch. 
TWEETEN, L \& ZAUF, C. (1998). Post industrial agriculture. Choices. Second Quarter: 30-33.

VAN DER WALT, W. (1997). South Africa: leader in African seed trade. Asian Seed, Vol. 4 no 3, June 1997:7 - 8.

VAN ROOYEN, C.J., ESTERHUIZEN, D. \& DOYER, T. (1999). How competitive is the South African agro-food industry. Contributed paper presented at the 37th Annual Conference of the Agricultural Economics Association of South Africa, Mykonos, Langebaan. 29-30 September 1999.

VENTER, H. (1999). Personnl commmnication. Fertiliser Manufacturers Association of South Africa, 23 August 1999.

WOLF, S.A. \& WOOD, S.D. (1997). The effects of precision farming. Rural Sociology. 62 (2):180-206.

ZILBERMAN, D., YARKIN, C. \& HEIMAN, A. (1999). Agricultural Biotechnology: Economic and International Implications. In: Peters, $G$ and Von Braun, J. (eds). Proceedings of the 23rd Intermational Conference of Agricultural Economists. Dartmouth.

ZUURBIER, P. (1999). Supply chain manngement. Unpublished lecture notes presented at a seminar at the University of Pretoria, August 1999. 